\title{
HJEM UDEN BØRN
}

\author{
TINE TJØRNHØJ-THOMSEN
}

Det var et ønske for os begge to at få et hus med have med henblik på at få det her hjem med familie (barnløs mand).

Denne artikel belyser, hvordan ufrivilligt barnløses håb om børn og deres forestillinger om et godt børne- og familieliv kædes tæt sammen med tanker og planer om anskaffelse og indretning af bolig. ${ }^{1}$ Formålet er at undersøge, hvordan ufrivilligt barnløse konstruerer sammenhænge mellem børn, hus, hjem, familie og slægtskab og derigennem stille skarpt på slægtskabets materielle dimensioner. Artiklens teoretiske grundtema vedrører således det uadskillelige og dynamiske samspil mellem socialitet og materialitet, som i de seneste år på ny har optaget antropologer (jf. Sjørslev 2007a, b; Hastrup 2004, 2006), og som også har manifesteret sig i en række nyere tilgange til slægtskab (se Carsten \& Hugh Jones 1995; Joyce \& Gillespie 2000; Birdwell-Pheasant \& Lawrence-Zúñiga 1999).

Artiklen er baseret på et feltarbejde i Danmark, der fokuserede på ufrivillig barnløshed, forplantningsteknologi og slægtskab og foregik i årene 1995-1999 (Tjørnhøj-Thomsen 1999a). Feltarbejdet omfattede blandt andet deltagerobservation i en forening for ufrivilligt barnløse og gjorde det muligt at følge flere barnløse par i en længere periode. Mange foreningsmøder, „kaffemøder“, som de blev kaldt, foregik i medlemmernes private hjem, ligesom også interviewene med de barnløse par. ${ }^{2}$ Det er observationer fra disse møder og de barnløses fortællinger om de afsavn, der er forbundet med barnløsheden, der er det primære empiriske materiale i nærværende sammenhæng. I artiklen inddrager jeg også andre undersøgelser af familie og hjem, fortrinsvis fra en skandinavisk og euroamerikansk kontekst, samt egne observationer fra andre empiriske kontekster i Danmark, som forbinder hus, hjem, familie og børn.

De barnløse pars håb, overvejelser, refleksioner og handlinger åbner et vindue til en mangestrenget forståelse af slægtskab, fordi de ekspliciterer kulturelle 
forhold og praksisser, der almindeligvis tages for givet. ${ }^{3}$ Når børnene ikke kommer som planlagt og forventet, må de barnløse revidere og gentænke, hvad de tidligere tog for givet om reproduktion, børn og familieliv. De stilles over for nye og uforudsete spørgsmål og valg, fx: Hvordan skal de få børn? Skal de gå i fertilitetsbehandling? Skal de bruge donor eller søge adoption? Hvor længe skal de fortsætte en belastende behandling? Skal de leve et liv uden børn? Skal de købe hus eller ny bolig? Hvor stort skal det være, og hvor skal det ligge?

Ønsker og håb om børn er, viser det sig, sammensatte, mangesidige og kønnede (se Tjørnhøj-Thomsen 1999a, b, 2003, 2004). De handler om autenticitet og om at blive, hvad der empirisk benævnes ,rigtig“ - mand, kvinde og familie. De handler også om en række tidslige dimensioner af slægtskab, som peger på begreber som reproduktion, succession, kontinuitet og generation, og som er tæt forbundet med ønsket om at videreføre sig selv og familien, blive husket og forbundet i tid. Mange af de billeder, de barnløse bringer i forgrunden, når de taler om længslen efter børn, er tillige hentet fra gode, sansetætte familieoplevelser fra deres egen barndom, som de håber at kunne genskabe med deres egne børn. Endelig er ønsket om børn forankret i behovet for at blive del af de mange sociale fællesskaber og samværsformer, som børn giver adgang til. At få et familieliv med børn og blive aktør i de socialitetsformer, familien både omgrænser og tager del i, er et af de mest fremtrædende temaer i de barnløses fortællinger. Det forbinder det eftertragtede familieliv med et utal af hverdagsagtige aktiviteter både i hjemmet og uden for det. Familielængslerne retter sig mod helt almindelige hverdagssamvær og -rutiner (fx spise og gøre trivielle hverdagsting sammen, cykle med et barn i en barnestol, lege i snevejr), deltagelse i forældremøder, skovture, sportsbegivenheder og at blive forbruger af børneting (Tjørnhøj-Thomsen 1999a). Men længslerne eksponeres også ved højtider, især i forbindelse med jul og fastelavn, hvor de fleste sociale aktiviteter har børn og børnefamilier som centrale målgrupper og aktører. Ufrivillig barnløshed accentuerer familiens og slægtskabets mange sociale, kulturelle, eksistentielle og - som det vil fremgå - materielle dimensioner. Det er sidstnævnte, og altså mere specifikt samspillet mellem socialitet og materialitet, som det iscenesættes og konfigureres i de barnløses håb og længsler om børn, der er denne artikels fokus.

Socialitet er, skriver den danske antropolog Inger Sjørslev, et „luftigt“ begreb, der vedrører det „relationelle“, det, der er mellem mennesker, som netop ikke er materielt, men som ofte fordrer materialisering for at kunne performes (Sjørslev 2007b:198). Socialitet er „måder at være sammen på““ (Sjørslev 2007a: 13) og handler om de menneskelige grundbetingelser, ,der kommer af at være et enestående individ og samtidig del af et fællesskab" (ibid.). Familien kan anskues som en socialitetsform og skal håndtere samme grundbetingelser. Den so- 
cialitet, der kendetegner familielivet, er fx informeret af slægtskabets „code of conduct" (jf. Schneider 1980), altså af kulturelt forankrede retningslinjer for, hvordan slægtninge bør omgås, og hvilke forpligtelser, udvekslinger og ansvar det at være $e n-o g i$ - familie indebærer. Familiens socialitet er også informeret af de mange specifikke opgaver, som familien forventes at løse. Det vil sige opgaver vedrørende residens, reproduktion, konsumption og socialisering.

Materialiteten er, som Sjørslev påpeger, afgørende for, hvordan socialiteten formes, men socialiteten former og inddrager også det materielle. At opretholde en skelnen tjener således et primært analytisk formål. I artiklen viser jeg, at omgivelser, boliger og ting ikke kun er scene eller kulisser for en bestemt måde at være sammen på, men skabes, formes og indgår i det sociale samvær (BirdwellPheasant \& Lawrence-Zúñiga 1999:2). Familiens socialitet udfolder sig med andre ord i samspil med huse, omgivelser, rum, ting og forskellige objekter. Samspillet mellem materialitet og socialitet må forstås med reference til specifikke sociale aktører og deres håb, motiver og handlinger. Det kommer også til udtryk i de måder, hvorpå mennesker generelt tillægger ting særlige betydninger som fortællingsbærere og som skabere og vedligeholdere af forbindelser mellem mennesker i tid og rum (Sjørslev 2007b:181; se også Empson 2007; Ryborg 2008), og samspillet fortættes fx i en særlig form i begrebet hjem (se fx Boholm 1983; Gullestad 1984, 1993; Rosengren 1991).

De barnløse indtager en særlig empirisk position, fordi børnene og de mange forskelligartede ting og aktiviteter, der følger med at få og have børn, primært eksisterer som forestillinger, forventninger og håb. Den særlige konfiguration af socialitet og materialitet, de eftertragter, er en projektion i tid og involverer personer, der ikke er blevet til endnu, og dermed også ting, der endnu ikke er anskaffet. Som da en mand fortalte, at han ikke kunne lade være med at bemærke andre mænds cykler med barnestole bagpå. Hans håb var, at der også en dag ville komme en barnestol bag på hans cykel.

Men selv om de barnløse ikke (skønt de sagtens kunne) erhverver sig specifikke ting til børn, før der er sikkerhed for, at barnet bliver en realitet, så materialiserer ønsket om børn sig ikke desto mindre i huskøbs- og indretningspraksisser. I det efterfølgende afsnit er det huskøbet, der er i fokus for diskussionen af slægtskabets materielle implikationer.

\section{Hus med børn in mente}

De barnløse i min undersøgelse lagde ofte en selvironisk distance til de mange penge, de havde „spildt på prævention“, og på deres egne forsøg på en hensigtsmæssig timing af børn. De havde i årevis forsøgt at undgå uønsket graviditet 
og havde, som folk flest, gjort sig overvejelser om, hvornår de skulle have børn, og hvilke betingelser der skulle være opfyldt, før de var „klar“ til børn, som nogle udtrykte det. Disse overvejelser og konkrete timingsbestræbelser afspejler en række socialt og kulturelt betingede forestillinger om reproduktionens rette kontekst og vilkår. Ansvarlighed, forpligtelse og stabilitet var fx nogle af de moralske imperativer, der blev angivet som forudsætning for at sætte børn i verden. Ungdomslivet præget af en uafhængig, spontan og individualistisk livsførelse (fx gøre ,spontane ting“ og ,gå i biografen og blive væk hele natten, hvis det er det, man har lyst til“" og „købe sig en egoistbolig eller en topersoners sportsvogn“, som en mand fortalte, da han pegede på de fordele, der trods alt var ved at være barnløs) måtte under alle omstændigheder lægges på hylden til fordel for et socialt forpligtende liv med en vis økonomisk og social sikkerhed (Tjørnhøj-Thomsen 1999:70ff.). Som en af kvinderne forklarede:

I de forhold, jeg havde haft, indtil jeg var 30, havde jeg aldrig haft noget ønske om at få børn. Jeg syntes, jeg var for ung, eller at det var for ustabilt. Jeg hører helt klart nok også til dem, når jeg ser i bakspejlet [tænkepause], det var noget med, at det hele skulle være villa, Volvo og vovse. Jeg var bestemt ikke indstillet på at tage chancer.

Den børneorienterede livsomlægning retter sig mod socialt stabiliserende aktiviteter, og her spiller erhvervelse af passende bolig en stor rolle. Livsomlægningen betyder også, at der må gives afkald på aktiviteter og tilhørende ting (fx sportsvogn og egoistbolig), der ikke umiddelbart forestilles at være foreneligt med et børne- og familieliv. Ungdomslivets særegne sociomaterielle konfigurationer må vige for andre.

At få et hus eller en lejlighed med plads og rum til børn er et tema, der bestandig dukker op i de barnløses fortællinger om deres forberedelser til de børn, der måske og forhåbentlig kommer. Nedenstående tilbageblik er uddrag fra et interview med et barnløst par. Det er et illustrativt eksempel på, hvordan mange af de barnløse par, selv om de ikke ønsker det, kommer til at indrette deres liv på forventningen om, at børnene snart kommer, og her indtager tanker om boligen en væsentlig rolle. En kvinde fortalte:

Alt, hvad vi har foretaget os her i vores ægteskab, efter vi er blevet gift, har jo drejet sig om, at i næste måned er jeg sikkert gravid. I november måned har vi været sammen i ni år. Vi har aldrig været på skiferie sammen. Fordi efter den tid, hvor vi fik råd til det, så nej, jeg er sikkert gravid, det duer ikke!

Kvinden fortalte også, hvordan både hun og ægtefællen havde sparet feriedage sammen og sørget for at have en god portion goodwill på deres arbejde ved at 
være fleksible og tage overarbejde, hvis de på et eller andet tidspunkt skulle i fertilitetsbehandling. Parret havde oprindelig en toværelses lejlighed og søgte en treværelses, men fik så tilbudt en fireværelses, som de følte, de var nødt til at tage:

Vi havde planlagt ferie og havde bestilt en rejse til Spanien, men vi var nødt til at tage den fireværelses, fordi hvis jeg nu blev gravid i næste måned, så duede det $\mathrm{i}$ hvert fald ikke med en toværelses, for der skulle være ordentlige forhold til barnet. Så ferien den blev bare lige afbestilt og droppet, og vi mistede vores depositum, for vi skulle have den fireværelses.

Men parret overvejede også at købe hus: „Alle folk spurgte os: Skal I have hus? Uh nej, for nu skulle vi snart have børn, og det havde vi ikke råd til så, for barnet koster så og så meget.“ Parret blev dog alligevel enige om at købe et hus. Den eneste grund til, at kvinden gik med til at købe huset, var dog, at banken lovede, at der godt kunne findes $100.000 \mathrm{kr}$. ekstra, hvis de skulle behandles på en privatklinik eller adoptere. „Alt bliver styret af det,“ som hun sagde. „Så kunne vi lige så godt tage et med to børneværelser.“ „Og der var også plads til at lave et ekstra værelse, hvis der nu kommer tre," som manden tilføjede. Parret gjorde sig ikke kun overvejelser om husets indretning, størrelse og udvidelsesmuligheder, men også om beliggenheden. Huset skulle ligge i ,grønne, stille rolige omgivelser langt væk fra byen, hvor de [børnene] ikke kan komme ud i noget skidt. De skal ud og lege med kornet på marken. De skal have nogle planter og træer og være, hvor der er andre børn på vejen. Og den lokale skole er en lille skole, hvor lærerne har bedre kontakt med børnene. Så langt er vi ude," som kvinden udtrykte det.

Interviewuddraget illustrerer, hvad der gør sig gældende for mange ufrivilligt barnløse par: at håbet om børn og venten på behandling gennem en længere periode kan påvirke beslutninger og dispositioner vedrørende ferie, arbejde, økonomi og bolig. I dette konkrete tilfælde er der ikke kun tale om at låne til et børnevenligt hus, men også at sikre sig, at disse økonomiske dispositioner ikke samtidig forhindrer, at der kan lånes penge til fertilitetsbehandling på en privatklinik, hvis behandlingen ikke lykkes i det offentlige. Eksemplet peger også på, at huskøbet er en signifikant begivenhed $i$ et livsforløb, fordi det kobler familiedannelsen med en betydningsfuld økonomisk investering (jf. Gullestad 1984), en investering, som fordrer gode lånemuligheder, bankforbindelser og fradragsmuligheder.

Mange tv-reklamer om boliglån retter sig da også mod unge par og spiller mere eller mindre eksplicit på forventningerne om den sociale udvidelse, som børn bibringer, og som nødvendiggør en fysisk udvidelse af boligen. Unge par og deres formodede familieskabelse gør dem til en vigtig målgruppe for ejen- 
domsmæglere, banker og kreditforeninger. En af de barnløse kvinder fortalte, hvorledes hun og ægtefællen havde været ude og se på et nyt hus sammen med ejendomsmægleren, som forsøgte at sælge huset netop med henvisning til de mange potentielle børneværelser, og som dermed også tog ønsket om børn og en pladskrævende familieudvidelse for givet. Kvinden havde ikke kunnet få sig selv til at fortælle den begejstrede mægler, at hun formodentlig ikke - uden videre i hvert fald - kunne få børn. Også boligannoncerne forholder sig til børn og familieliv og adresserer i beskrivelsen af husets indretning og beliggenhed forskellige dimensioner af familielivets socialitet: Her annonceres for huse, der skaber „perfekte rammer for den store familie“, at der er „alrum, hvor familien kan samles“, at der er „2 eller flere gode eller rummelige børneværelser" eller ligefrem en ,stor børneafdeling“ (min fremhævning). Beskrivelsen af husets beliggenhed retter sig også imod børnenes udfoldelsesmuligheder og det daglige familielivs logistiske udfordringer: Her noteres „en god beliggenhed i grønne områder med legeplads“, at området er „utroligt børnevenligt“, eller at der er ,indkøbsmuligheder, skoler, daginstitutioner i lokalområdet“" eller i ,gåafstand“ (Ejendomsavisen Danbolig 2008).

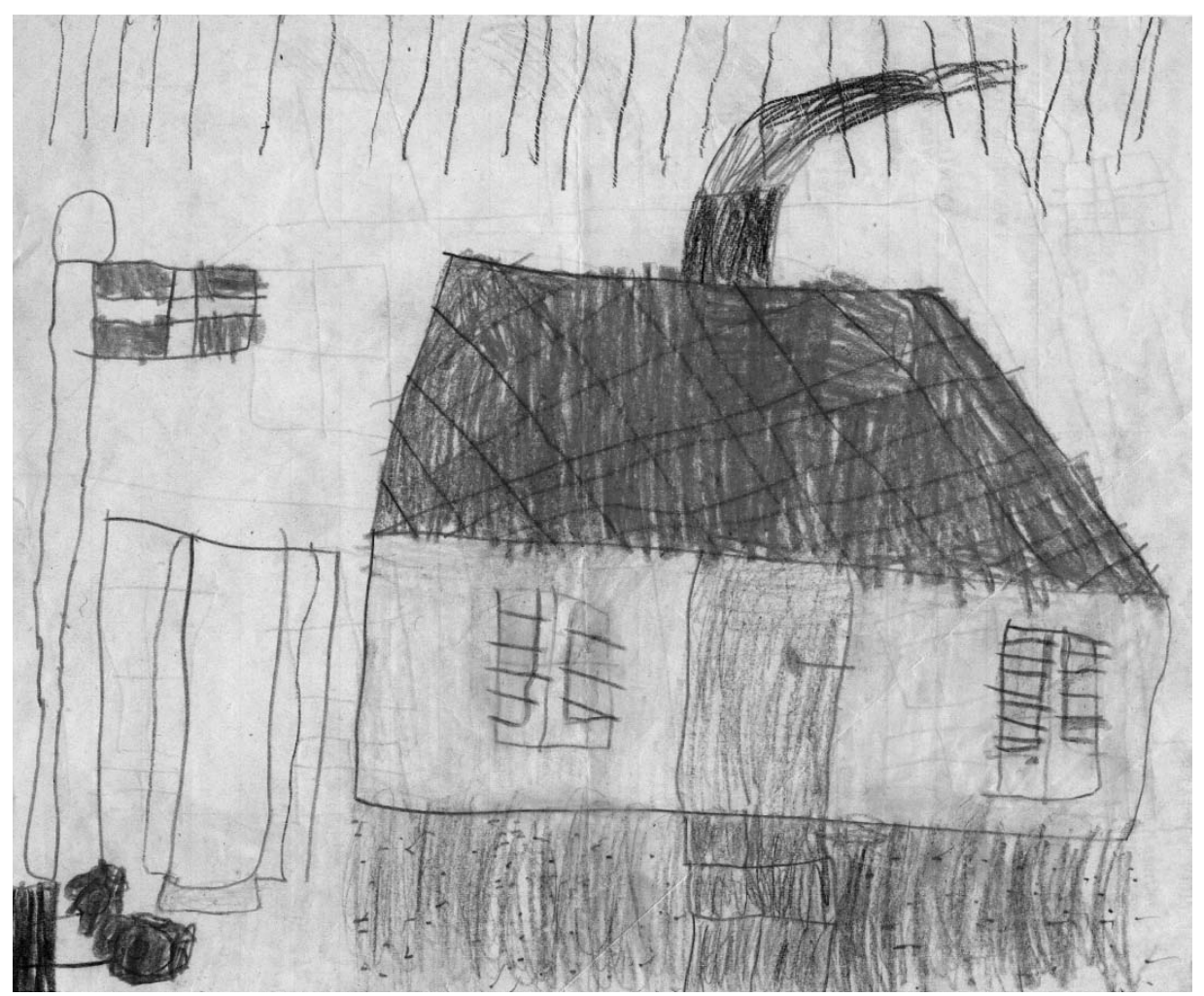

Tegning af Kirsten, 5 år. 1949. 
De barnløse og Ejendomsavisen Danbolig anslår i fællesskab to temaer: For det første skal børnene have egne og gerne rummelige værelser, og der skal i udgangspunktet være plads til flere børn. Parrene i min undersøgelse drømte alle om at få mere end ét barn. Både de og Ejendomsavisens annoncer omtalte bestandig børn og ikke mindst børneværelserne i flertal og indikerede, at familielivets socialitet fordrer mere end et barn. Men hvorfor egne værelser?

Selve den idé, at børn har krav på egne og særligt indrettede rum, er historisk set forbundet med udskillelsen af barndommen som en særlig og anderledes livsfase, hvor børnene blev genstand for øget uddannelse og opdragelse, og hvor skolen og familien blev de primære socialiserende instanser (Rosenbeck 1987: 190-1; se også Aries 1962; Zelizer 1985). I det bedre borgerskab i Vesteuropa og Skandinavien fik børnene først mod slutningen af det 19. århundrede eget værelse efter tidligere at have sovet med tjenestefolkene (se Gillis 1996; Löfgren 2003). Børneværelsernes fremkomst skriver sig endvidere ind i den generelle udvikling af de funktionsopdelte hjem. Men det var først i slutningen af 1950'erne, at børneværelset blev en selvfølgelighed i danske hjem (Winther 2006:78) og derefter nærmest en forældrepligt og børneret (ibid.). Børnene er i stigende omfang - fra det 20. århundredes begyndelse - kommet til at udgøre et stort marked for kommercialisering og afsætning af varer som legetøj og tøj (Rosenbeck 1987: 191).

Kravet om et eget og særligt indrettet børneværelse besegles således af kommercialiseringen af børneområdet. En rundtur på IKEAs hjemmeside ${ }^{4}$ er blot én indikation på den store kommercielle opmærksomhed på børneværelsernes indretning. Der er tip og ideer at hente i „Bo med børn“, og et klik derfra er siden „Velkommen til børnenes IKEA“, hvor varehuset gør opmærksom på, at „børn er de vigtigste mennesker i verden, og leg er det vigtigste, der findes", og at varehusets møbler skal kunne holde til denne leg. Her fremgår det også, at IKEA lærer, hvad børn har brug for, gennem samarbejde med førende børneeksperter. Forbrugeren kan derefter klikke sig ind på færdigindrettede værelser til forskellige aldersgrupper. Forbrugsdimensionen er slet ikke uvæsentlig i denne forbindelse.

De barnløse mænd og kvinder (og ikke mindst deres forældre, de potentielle bedsteforældre) lagde ikke skjul på, at de også længtes efter at blive forbrugere på det omfattende marked, der har med børneudstyr og børneværelsesindretning at gøre. Den amerikanske antropolog Linda Layne påpeger analogt hertil, at det at købe ting og gaver til sine børn er en af forældreskabets mest betydningsfulde gerninger i Nordamerika (Layne 2000). Laynes studie handler om forældre, der har aborteret spontant eller mistet deres barn ved fødslen. Hun viser, hvorledes forældrene gemmer ting (fodaftryk, hår og ting og gaver til barnet) i små minde- 
æsker, for derved at understrege - og opnå erkendelse af - at barnet og tabet af det var virkeligt. Laynes informanter sørger over ikke at kunne købe ting og gaver til deres børn og begræder den tabte forbrugsmulighed (op.cit.326). De ufrivilligt barnløse i Danmark oplevede også afsavnet ved at være udelukket fra dette særlige børnefokuserede forbrugsfællesskab, men de havde håbet og muligheden i behold.

Børnenes IKEA er endnu et godt eksempel på samspillet mellem socialitet og materialitet: De specifikke, ekspertudviklede børneting, legetøj og værelsesindretninger, og markedsføringen af dem ikke mindst, rummer budskaber om, hvad der er godt for børn, og hvad der er god socialisering, og sender stærke signaler om, hvordan det gode forældreskab bør forvaltes. Dette leder mig til det andet tema:

For huskøbsovervejelserne vedrører også de sociale og socialiserende implikationer af husets indretning og beliggenhed. Det er børnenes fremtid, der er på spil. Børnene skal i små skoler og tæt på naturen og dens formodede positive effekt på et børneliv og helst langt væk fra byens potentielt dårlige påvirkning. I føromtalte pars forestillinger om boligens beliggenhed tegnes et næsten nostalgisk billede af børnenes kollektive og uforstyrrede leg på vejen, der muligvis var en realitet i Danmark i 1950'erne, men siden er blevet et sjældent syn.

Håb og ønsker om børn giver altså umiddelbart anledning til overvejelser om huskøb, husets indretning, størrelse og sociogeografiske lokalisering, og disse overvejelser indlejrer samtidig visioner om et godt familieliv og gode opvækstog udviklingsvilkår for børn. I det efterfølgende afsnit flyttes blikket ind i de erhvervede huse, hvor de halvtomme rum på en og samme tid materialiserer håbet om og fraværet af børn.

\section{Tomme rum}

Huset er nyt og stort, og vi, der har været på besøg, bliver vist rundt også på husets første sal, inden vi tager hjem fra aftenens sammenkomst. Der er meget plads. 'Til masser af børn,' er der én, der siger ironisk. 'Ja,' siger husværten. 'Vi har også meget plads, for vi skulle jo have mange børn.' Parret har købt hus ca. 60 kilometer fra København, men har ikke kunnet afhænde en lejlighed i København. Så den har de jo også, som en af de tilstedeværende påpeger. Husværten svarer i samme ironiske tonefald: 'Ja, det er jo til, når ungen skal studere.'

Mange møder og interviews undervejs i feltarbejdet foregik i private hjem. I nogle tilfælde var der tale om relativt nyindkøbte huse, som var ved at blive istandsat. Det gjorde det oplagt som del af det sociale samvær at blive vist rundt og se på rummenes placering og diskutere deres kvaliteter og muligheder. Sådanne rund- 
visninger er en almindelig foreteelse i Danmark, når venner og bekendte har købt nyt hus. De vidner om, at selv om hjemmet opfattes som det sted, hvor det private og intime liv udfolder sig og har hjemme, så bliver hjem også vist frem som markeringer af familieskab, status, økonomisk formåen, livsstil, klasse, god smag, gør det selv-kompetencer m.v. (jf. Gullestad 1984; Rosengren 1991). Både Marianne Gullestads og Annette Rosengrens antropologiske og etnologiske studier fra henholdsvis Norge og Sverige beskriver det store arbejde og de mange ressourcer, især kvinder bruger på at indrette, pynte, organisere og skabe hjemmet, så det både fungerer indadtil i forhold til familien og samtidig tåler fremmede blikke (Gullestad 1984; Rosengren 1991).

De fleste par i min undersøgelse, der havde erhvervet sig hus, havde købt det med børn i tankerne, og de havde også klare forestillinger om, hvor børneværelserne skulle være. De forestillede børneværelser stod dog hverken helt tomme eller færdigindrettede til noget specifikt, velartikuleret formål. De var gæsteværelser, opbevaringsrum eller kontoragtige og altså præget af en vis midlertidighed og potentiale. Men værterne lagde ikke skjul på hensigten med de specifikke rum over for de andre barnløse, og ofte, som illustreret ovenfor, skete det med et gran af selvironisk distance. De delvis tomme rum var på en og samme tid et symbol på barnløsheden og en materiel eksponering af et uønsket fravær af børn og familieliv. Men de var også fremvisning af håbet om at få og drage omsorg for børn - ja, endda med tiden sikre dem gode uddannelsesvilkår. Her er børnenes fremtid og muligheder igen på spil. Men de tomme rum stod også som en sarkastisk kommentar til forventningen om, at børn kommer, når deres potentielle forældre er klar til at få dem.

Når først beslutningen om børn er truffet, så bliver der „tomt", forklarede en kvinde. Hun havde engang læst en bog, hvor der stod, at „,voksne uden børn er tomme voksne“, og „det føler jeg egentlig lidt“, sagde hun. Når parret havde deres nevøer på besøg, var der „liv og glade dage“, mens „der er mere stille, når man kun er to. Der føles tomt på en eller anden måde“. Tomheden har flere manifestationer, der her forbindes metaforisk: Den refererer til en indre tilstand af afsavn og mangel på livsfylde, som børn forventes at bidrage med. Tomheden refererer også til de faktiske tomme rum, til fraværet af børnerelevante ting i rummet og støjende børn, der materialiserer manglen på børn i huset. Det tomme og stille hus bliver derved en fysisk, materiel og sanselig eksposition dels af kvindens udhulede selvfølelse, dels af den manglende familiesocialitet. 


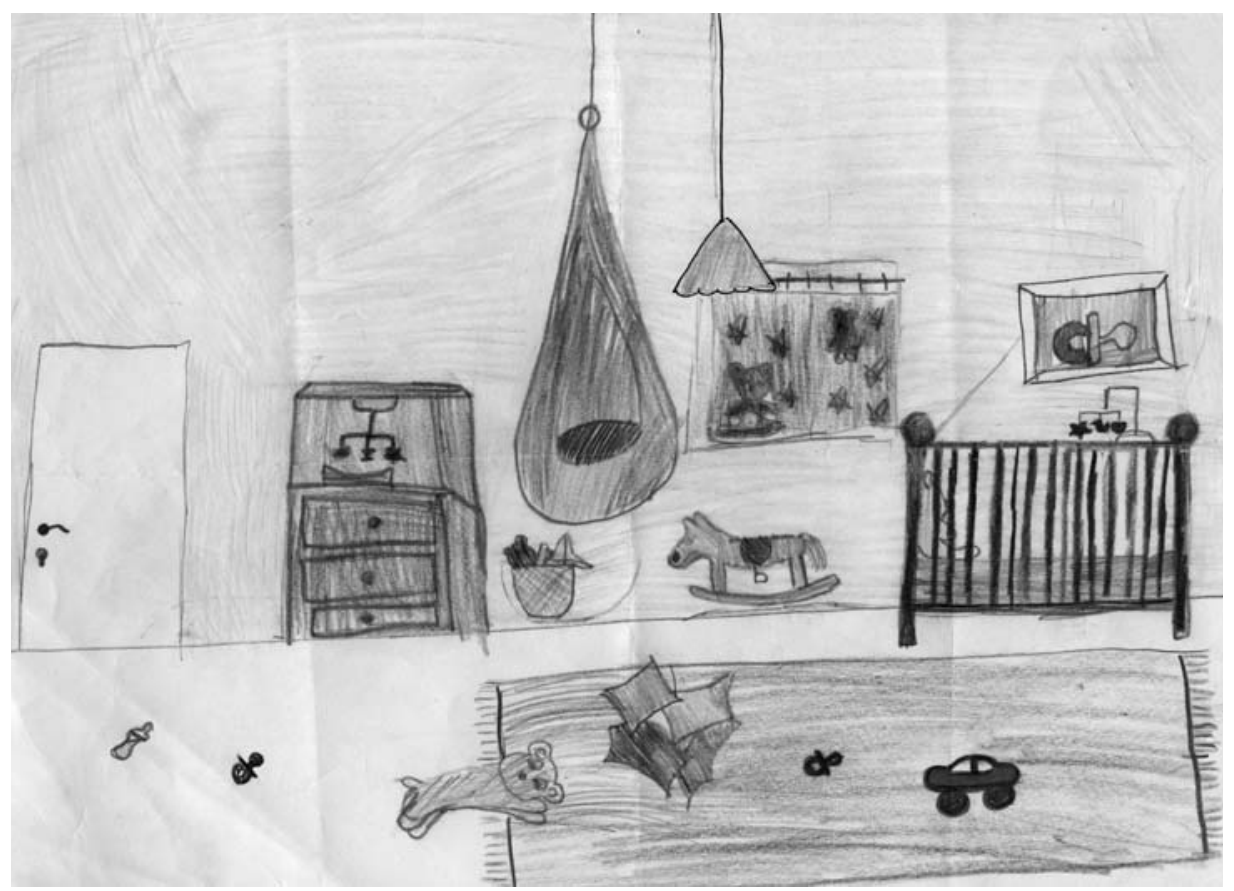

Tegning af Juliane, 9 år. 2009.

\section{Husindretning og nemesis}

Forholdet mellem familieskabelse og husindretning er på spil på en særlig måde i de barnløses planer om at skabe særlige rum og plads til flere børn. Men som eksemplerne nedenfor vil vise, garderede de sig også mod nemesis ved ikke for tidligt at færdigindrette børneværelserne.

En kvinde huskede tydeligt sin fars kommentar til det nye hus, som parret ikke lagde skjul på var købt med børn in mente. Under fremvisning af værelserne havde faderen udpeget et hjørne i soveværelset: „Dér kan vuggen stå,“ foreslog han. Dette forslag blev mødt med nogen ambivalens. For selv om kvinden satte pris på faderens engagement $\mathrm{i}$ indretningen af huset og så det som udtryk for en glædesfyldt forventning om at blive bedstefar, var hun efter adskillige mislykkede fertilitetsbehandlingsforsøg usikker på, om der nogensinde kom til at stå en vugge. At tale så direkte og højlydt om vuggens placering var, syntes hun, at udfordre skæbnen. 
Men skæbnen lod sig ikke udfordre i negativ retning. Et år senere lykkedes det for parret at opnå graviditet. Kvinden fortsatte med at komme til kaffemøderne i foreningen for ufrivilligt barnløse. Ægtefællen havde imidlertid ikke tid til at deltage i møderne mere, for han arbejdede intenst efter arbejdstid på at gøre børneværelset klart. Tre måneder før forventet fødsel stod det færdigt. Men, som han fortalte, ,jeg har ikke flyttet ting derind endnu, for det kan gå galt for os alle sammen".

Angsten for nemesis og dens aftryk i timingen af boligindretningen og køb af børneting var meget fremtrædende i mit etnografiske materiale. At købe børnetøjet for tidligt eller flytte barnevogn og andre børneting ind i huset og melde endegyldigt fra til medlemsmøderne, før barnet var født, var udvisning af et overmod, der let kunne påkalde sig skæbnens eller gudernes vrede og hævn. Frygten for skæbnehævn blev forstærket af, at mange par havde flere mislykkede behandlingsforsøg og skuffelser bag sig, og de passede på, som en kvinde udtrykte det, ,ikke at juble for tidligt“, hvis det viste sig, at behandlingen gav resultat. Usikkerheden om fertilitetsbehandlingens resultat afspejles også i eksemplet nedenfor, hvor det håndteres på en anden måde:

Da et af parrene overvejede at købe hus, var det et kriterium, at der skulle være et børneværelse. På det tidspunkt var parret i behandling for barnløshed. Da de besluttede sig for at købe huset, tænkte de, at det var lidt småt, hvis der nu kom et barn. Men som kvinden sagde: 'Der er også hele tiden den der i baghovedet, at hvis der nu ikke kommer et barn, skal vi ikke sidde med en kolos af en bygning.' Efter adskillige mislykkede inseminationsforsøg ventede parret nu på at komme i IVF-behandling. De mange mislykkede forsøg havde ændret deres husindretningsovervejelser: 'Da vi købte huset, talte vi om, hvilket værelse der skulle være børneværelse, hvis der kom et barn. I dag siger vi: Det værelse skal bruges til det, og det værelse skal bruges til det. Og hvis en af os kommer til at snakke om, hvad hvis nu (vi får børn) så siger vi til hinanden: Det problem løser vi, når det opstår. På den måde har det distanceret sig. I starten tænkte vi meget på indretning af stuen, og hvis der nu skulle stå en kravlegård, hvor skulle den så stå. I dag siger vi: Den kommer til at stå, hvor der er plads til den. Og der skal nok blive plads. Ikke?'

Mange par bestræber sig som i dette eksempel på at trodse det belastende hvisnu-liv. De forsøger aktivt og eksplicit at modsætte sig, at håbet om de børn, der måske kommer, skal styre deres liv og beslutninger og i dette tilfælde beslutninger om indretning af huset. I ovenstående eksempel bruges værelserne meget offensivt til noget andet, og tiden ses an. Parret ønsker ikke, at erhvervelsen af et for stort hus med for meget plads skal komme til at stå som en mindestue - et memento - om de børn, der aldrig kom (jf. Boholm 1983). Mindestuer og arvestykker bærer på fortællinger om personer, der har levet. Man kan endda sige, at de er med til 
at gøre disse personer virkelige og enestående. Det er det, Laynes informanter gør, når de gemmer gaver til deres ufødte børn eller hår eller fodaftryk fra deres spontant aborterede fostre eller dødfødte børn (Layne 2000). Men mindestuer for børn, der aldrig blev til, for ikke-personer, giver ikke mening.

\section{Fra hus til hjem}

De tomme rum er ikke kun en fysisk markering af manglen på de børn, parrene havde forventet og indrettet sig på skulle komme. De er, som det fremgår ovenfor, også en både symbolsk og fysisk markering af mangel på et ønsket familieliv. Men der er mere på spil: at skabe et hjem. Ønsket om børn verbaliseres ofte som et ønske om at få familie og skabe et hjem, som det også udtrykkes i artiklens indledende citat: at få hus og have for at få hjem og familie.

Næsten samme skelnen mellem hus og hjem beskrives af den amerikanske antropolog David M. Schneider i hans bog om nordamerikansk slægtskab. Han skriver, at ,huset er det sted, hvor familien lever, måden, hvorpå familien lever der, er det, der kan gøre det til et hjem" (Schneider 1980:45). Et hus er i denne udlægning ikke per definition et hjem. Det er børn og familieliv og de særlige handlinger, aktiviteter, visioner og følelser forbundet hermed, der transformerer huset til hjem (se også Low 1996; Löfgren 2003).

Flere antropologer har forsøgt at definere og udrede forskelle og relationer mellem begreber som hus, hushold, hjem og familie analytisk (Birdwell-Pheasant \& Lawrence-Zúñiga, 1999). ${ }^{5}$ Groft sagt er tendensen i de forskelligartede definitionsbestræbelser, at hus kobles til bygning, ly, bolig, til fysisk struktur (på engelsk, shelter, building, dwelling).

Det samme gør sig gældende i ordbøger om dansk sprogbrug. I en tidlig udgave af Ordbog Over Det Danske Sprog (ODS) fra 1966 angives hus at være en ,bygning ( $\mathrm{m}$. vægge og tag), som udgør en selvstændig enhed, brugt til bolig (opholdssted, samlingssted) for mennesker (og dyr) eller opbevaringssted for noget“"(ODS 1966 bd. 8:708). Et hjem defineres som ,hus eller lejlighed osv., der er en persons el. især en families faste bopæl“. Ordbogen påpeger, at hjem næsten kun bruges om „boligens indre (lejligheden, stuerne, m. indbo, og hvad dertil hører) og oftest $\mathrm{m}$. henblik på boligen som sæde for familielivet, som sted, hvor man søger hvile, ro, hygge olgn. efter arbejdet" (op.cit.183, oprindelige forkortelser og parenteser). ${ }^{6}$ I Den Danske Ordbog fra 2004 står, at et hjem er ,en persons bolig, som udgør vedkommendes private tilholdssted, ofte med tanke på fællesskabet mellem de mennesker, som personen bor sammen med“" (Den Danske Ordbog 2004:718). Ordbogen nævner altså ikke familie, men betegner socialiteten dér som fællesskab og betoner samtidig hjemmet som et privat sted. ${ }^{7}$ 
Man kan sige, at hus begrebsligt bringer materialiteten i forgrunden, mens hjem integrerer det materielle (altså huset) med familie, særlige tilhørsforhold, oprindelse, følelser og sanser (jf. Gullestad 1993:131). Den nære forbundethed mellem hjem og familie er da også manifest i de skandinaviske og euroamerikanske undersøgelser, der er refereret til tidligere. For eksempel skriver Gullestad, at hjemmet er centralt som familiens territorium (Gullestad 1984; Löfgren 2003).

Da jeg spurgte de barnløse, hvad familie betød for dem, var det et ret entydigt billede, der tonede frem, og det matcher ordbøgernes: Familien er der ligegyldigt hvad og kan ikke til- eller fravælges (som fx venner). Familien omtales også som et fællesskab, et sted, hvor man kan ,,være sig selv“ og slappe af, og hvor „du“ i udgangspunktet bliver accepteret for „,det, du er“. Den nære association mellem familie og hjem og den måde, hvorpå samspillet mellem materialitet og socialitet konfigureres i begge begreber, bliver tydelig i nedenstående forklaring på, hvad familie er:

Jeg kan kun sige, at det er som en kold dag, hvor man kommer ind i en varm stue, hvor der sidder nogle mennesker. Det er familie. Fordi det har jeg stadig i mig, at jeg var ude med en ven i flere timer, hvor jeg blev iskold, der var en familie, som sagde: Stil dig hen ved ovnen, så bliver du varm, og så får du en kop kaffe, den tryghed ...

Familiens kvaliteter omtalt med ord som tryghed, varme, hygge, imødekommenhed og omsorg er lokaliseret $\mathrm{i}$ - eller materialiseres som - hjemmet, der på den anden side også huser særlige personer, aktiviteter, rum, atmosfære, varme og dufte (Simpson 1997; Löfgren 2003). Hjem forbindes i skandinaviske lande med varme, hygge, sikkerhed og fred, og der investeres meget tid og mange penge på kontinuert at indrette (og genindrette) og dekorere huset, så det signalerer disse værdier og lever op til ideen om et både trygt og pænt hjem (Gullestad 1984; Rosengren 1991).

Både tværkulturelt og historisk set er husbyggeri og husenes rumlige indretninger, og de aktiviteter, disse indretninger markerer, relateret til forestillinger om slægtskab, familie, klasse og køn (Carsten 1995; Gillis 1996). Historikeren John Gillis skriver, at det først var i midten af det 19. århundrede, at mennesker i Europa begyndte at tænke hjem som noget, familien selv etablerede, og som ikke refererede til det „himmelske“ hjem (Gillis 1996:110). Disse tanker lagde, påpeger Gillis, fundamentet til de moderne krav om hus og hjem.

Hjem har endvidere siden slutningen af det 19. århundrede været tæt forbundet med kvinder, moderskab og kvindelighed. Kvinder var hjemmets primære skabere og vedligeholdere og hovedansvarlige for at skabe et godt hjem, mens hjem for de udearbejdende mænd primært var et rekreativt terræn, de kom hjem til efter arbejdet (Rosenbeck 1987; Gillis 1996; Löfgren 2003). Der var enkelte 
mænd i min undersøgelse, der talte om længslen efter at „komme hjem“ til et hus med børn, og udsagn som disse kan fortolkes med reference til denne historisk og kulturelt betingede, kønnede arbejdsdeling mellem at voere (kvinde) hjemme med børnene og komme hjem (som mand). Selv om kvinderne for længst er kommet ud på arbejdsmarkedet og ikke går hjemme mere, men også kommer hjem (fra arbejde) så tyder meget på, at de stadig udfører det meste af „husarbejdet“, som det hedder (jf. Bonke 2002). ${ }^{8}$

Antropologiske og etnologiske undersøgelser foretaget i Skandinavien i 1980'erne peger som nævnt på kvinderne som de primære aktører i hjemmets kontinuerlige skabelse og genskabelse. Det betyder ikke, at mændene ikke deltager $\mathrm{i}$ beslutninger om husindretning og tager sig af større ombygninger, som i tilfældet med børneværelset i casen ovenfor, men de er ikke lige så interesserede i indretningsdetaljerne (se fx Rosengren 1991). ${ }^{9}$ I min undersøgelse var det mændene, der udførte det håndværkmæssige arbejde med at gøre huset klar til barnet, og det gjorde de også for at skåne deres gravide ægtefælle for det fysiske arbejde. De barnløse - ventende - mænd mente selv, de støvsugede langt mere, end mænd gør flest. Der var heller ikke på det område grund til at udfordre skæbnen.

Hjemmet betegner således det sted, hvor børn og voksne udfolder det særlige intime, eksklusive samvær og de aktiviteter, der er med til at definere familien, og som også kommer til udtryk i de barnløses længsler efter børn og i deres fortællinger om det familieliv, de selv er og har været del af. Familie kan ikke kun anskues som socialitet, men konfigurerer på særlig vis samspillet mellem socialitet og materialitet. Og selv om hjem begrebsligt og empirisk bringer materialiteten i forgrunden, kan dets særlige betydning kun forstås i samspil med en særegen socialitet.

\section{Hjem uden børn}

Barnløse hjem er ikke kun de, hvor børnene er stærkt ønskede, men ikke har indfundet sig. Der er en anden slags barnløse hjem, der bliver virkelige senere i livscyklen: nemlig de, hvor børnene er flyttet hjemmefra, og hvor børneværelsernes funktion derfor skal revurderes og justeres. Som vi så ovenfor, var børnenes nødvendige fraflytten også en tematik i de barnløses overvejelser om huskøb. Men de talte i futurum eller konjunktiv.

Det efterfølgende eksempel er i en slags datid. For i modsætning til de ufrivilligt barnløses hjem, hvor fraværet af børn materialiserer sig som halvtomme og afventende rum, har børnene i dette hjem for længst sat deres egne mærker. Huset har måttet bøje sig for deres tilstedeværelse og krav om individualitet og privathed. 
For år siden, da min mand og jeg som ungt par uden børneplaner var på weekendbesøg hos mine svigerforældre, overnattede vi altid i et af de gamle børneværelser på husets første sal. Med en slags sørgmodig ironi havde min svigermor ophængt et hjemmelavet skilt på rummets væg, hvor der stod „Mindestue for vor Lena“. Lena er min svigerinde, der som mange andre unge flyttede hjemmefra, tættere på København, for at uddanne sig. Nu stod hendes gamle værelse tilbage og indeholdt stadig nogle af de møbler, billeder og små ting og nips, hun tidligere havde benyttet og omgivet sig med, men altså havde ladt tilbage. I modsætning til de barnløses delvist tomme rum var rummet mærket af hendes særlige og individuelle tilstedeværelse. Men rummet indeholdt også andre ting, der var flyttet ind for at give bedre plads i andre rum: overskudsbøger og ting, der ikke blev anvendt for tiden. Så rummet lignede de barnløses delvist tomme rum, ved at de ikke rigtig var nogens og derfor blev anvendt til lidt af hvert. Langs væggen var der god sengeplads til os voksne børn, der, som det er stadig er almindeligt for mange unge studerende, blev forkælet med god mad og nul arbejde, når vi kom hjem, og udstyret med lidt ekstra, når vi søndag aften drog af sted igen. Værelserne ovenpå havde min svigerfar selv bygget som led i en kontinuer - ja, næsten livslang - ombygning af huset, der afspejlede familiens udvidelse, børneflokkens vækst og hensynet til de enkelte børns behov for særlige rum og privatliv.

Eksemplet illustrerer en særlig version af den memoralisme, som Åsa Boholm beskriver i sin studie af svensk slægtskab, og som vedrører de minder og fortællinger, der knytter sig til genstande og ting og derved skaber en slags social kontinuitet ved blandt andet at fiksere fortællinger om fraværende oftest afdøde personer. Boholm beskriver, hvordan huse, genstande, gaver, grave, fotografier, navne m.v. fungerer som mementos for slægtninge, personer eller særlige begivenheder. Disse ting forbinder levende personer med afdøde og med fortiden, og de opbevares og overdrages med henblik på at blive mementos i fremtiden. Tingene er dermed både udtryk for og bærere af social kontinuitet og forbundethed i tid (Boholm 1983:215-7). De er i sig selv fortællingsbærere (Sjørslev 2007b:181). Eksemplet understreger også en anden pointe, der er væsentlig i forståelsen af forholdet mellem hus, hjem og familie. Nemlig at hus og hjem er foranderlige, og at huset og dets indretning og hjemmets særegenhed tager form af familiens udvikling og cyklus. ${ }^{10}$ Husets materialitet og familiens socialitet konstituerer gensidigt hinanden over tid - som hjem.

Samme tematik, omend i en helt anden empirisk kontekst, beskrives af antropologen Rebecca Empson (2007) i antologien Thinking Through Things. Theorising Artefacts Ethnographically (Henare, Holbraad \& Wastell 2007). Empson beskriver, hvordan mongolsk slægtskab både kommer til udtryk og skabes gennem de måder, hvorpå specifikke ting eller objekter enten udstilles oven på 
en særlig husholdskiste, så besøgende kan se dem, eller gemmes i kisten, skjult for besøgendes blikke. Disse særlige kister findes i alle mongolske hushold. Det er forskellige ting, der enten gøres synlige (fotografier, ure, batterier, parfume) eller gemmes (hår, navlestrenge), og de refererer til en række forskellige slags slægtskabsrelationer og former for forbundethed. Pointen er, at man ved adskillelse mellem mennesker sørger for at bevare og gemme noget fra den person, der forlader husholdet, for derved at sikre, at relationen fortsætter og vedligeholdes. Det, man bevarer, indeholder noget af denne persons essens eller skæbne, og det tilbageholdes for at sikre helheden på trods af adskillelsen (op.cit.115). Tingene og de måder, hvorpå mongolerne forholder sig til dem, er på en og samme tid med til at vedligeholde og skabe relationer, og tingene $p a ̊$ eller $i$ kisten er, skriver Empson, således en måde at fastholde relationer mellem forskellige nulevende mennesker på trods fraværet af dem og dermed en måde at håndtere den evige sæsonmæssige flytning af mennesker og hushold på (Empson 2007:118-9).

Der er mange kulturelt og socialt betingede forskelle mellem Mongoliet, Skandinavien og USA i de måder, hvorpå slægtskab og forbundethed forestilles, tænkes og skabes gennem ting. Men i alle tilfældene handler det om at håndtere fraværet af slægtninge og slægtskabets foranderlighed og samtidig fastholde det ved hjælp af ting. De barnløse skal også håndtere et fravær, og også her spiller ting og materialitet en rolle. Fraværet udstilles i de halvtomme rum og i længslen efter at indrette særlige rum til børn, få en barnestol på cyklen eller blive forbruger og købe ting til børn på det bugnende børnemarked.

\section{Konklusion}

At ønske sig, få og have børn er nøje forbundet med forståelse af familieliv og hjem og er tæt relateret til erhvervelse og indretning af hus eller bolig og særlige ting. Også fra en barnløs optik er børn og familieliv det, der gør et hus til et hjem. Der er således en tæt og uadskillelig forbindelse mellem familie og hjem, som hver for sig byder på forskellige konfigurationer af samspillet mellem materialitet og socialitet. Familiens socialitet er informeret dels af ideer om slægtskab og forbundethed, dels af de særlige opgaver, som familien samfundsmæssigt forventes at løse. Her spiller overvejelser om hus, husindretning og husets beliggenhed uvægerligt med. De barnløses tanker og håb om børn og familie kan ikke adskilles fra tanker om husets indretning og beliggenhed: Husets tomme rum har sociale og emotionelle implikationer; tanker om husets indretning og beliggenhed er sammenvævet med ideer om det gode børneliv og børns rette socialisering; familie og hjem forbindes med følelser og sanser som tryghed, varme, nærvær og ubetinget kærlighed og er tillige kønnet. Endelig mærkes hjemmet og 
dets ting af specifikke personers beboelse af det og bær på den måde familiens historie videre.

\section{Noter}

1. Denne artikel er baseret på min ph.d.-afhandling, der mere indgående beskæftiger sig med de individuelle, sociale og kulturelle implikationer af de nye reproduktionsteknologier og dermed med det særlige samspil mellem socialitet og materialitet, der udfolder sig i denne kontekst. Dette aspekt er helt udeladt i denne artikel (men se Tjørnhøj-Thomsen 1999a, b, 2003, 2004).

2. Feltarbejdet omfattede også deltagerobservation på fertilitetsklinikker, adoptionskurser, medicinske konferencer og etiske høringer.

3. Selv om de barnløses situation er særegen, og man kan sige, at de kaster et særligt lys på slægtskab og familie, giver min undersøgelse ikke belæg for at konkludere, at de ufrivilligt barnløses håb og forventninger om slægtskab og bolig adskiller sig fra de mennesker, der făr børn på almindelig vis.

4. http://www.ikea.com/dk/da/catalog/categories/departments/childrens_ikea/. (30. juli 2008).

5. En del af definitionsbesværet beror også på, at der er stor overensstemmelse og sammenfald mellem europæisk folkeforståelse af forskelle mellem hus og hjem og en antropologisk diskurs og begrebssætning af samme, ganske som det har været tilfældet med slægtskab (jf. Schneider 1984). Altså at antropologers tilgang til hushold, familie og hus er rodfæstet i europæiske folkemodeller af domestisk aktivitet. Det er en vigtig begrundelse for, at udvikle andre begreber til forståelse af familie og hjem, og her er en tilgang, der fokuserer på forholdet mellem materialitet og socialitet, et godt bud.

6. Hjem kan også være et landområde. Men det er kendetegnende, at det er følelse af tilknytning gennem slægtskabsbånd, hjemstavns- eller nationalfølelse, der bringes i forgrunden.

7. Til gengæld giver ordbogen en række sprogbrugseksempler, der viser hjems komplekse betydninger, og hvorfor hjem er så vanskeligt at definere entydigt for samfundsforskere: Man kan tale om „,ens andet hjem“ og om at „gå fra hus og hjem“. Når noget foregår ,inden for hjemmets fire vægge“", er det privat og vanskeligt at få adgang til for hvem som helst og det, der foregår dér, står i modsætning til livet udenfor. Hus og hjem kan siges at markere grænser mellem det offentlige og private og giver dets beboere mulighed for at kontrollere, hvem der får adgang og hvem ikke, og dermed også mulighed for at regulere, hvad der skal skjules, og hvad der skal udstilles. For hvor meget hjemmet end forbindes med privatlivsfred, fremvises det også til andre, som jeg senere skal give nogle eksempler på. Man kan også „komme fra et hjem med klaver", hvilket indikerer, at man kommer fra et velstillet og velopdragende hjem (Den Danske Ordbog 2004:718).

8. Når de voksne barnløse (og det var oftest kvinderne) opsøgte deres barndomshjem og forældre og skulle fortælle om barnløsheden eller trøstes, var det ofte i første omgang moderen, de tyede til. Som i andre undersøgelser af slægtskab og familie fremstår også kvinderne i min undersøgelse som de signifikante og dominerende aktører, når det gælder vedligeholdelse af slægtskab og familierelationer (se Tjørnhøj-Thomsen 2004).

9. En undersøgelse af mandlige og kvindelige plejehjemsbeboere i Danmark peger også på, at mænd og kvinder indretter deres værelse på plejehjemmet meget forskelligt. Kvinderne indretter deres plejebolig, så den så vidt muligt ligner deres tidligere - og rigtige - hjem. De pynter værelserne med nips og genstande (og med potentielle arvestykker). Mændene er langt mere pragmatiske og går ikke særlig meget op i indretningen af deres værelse, som ofte præsenterer sig som opbevaringsrum (Ryborg 2008:21-2). 
10. En af de seneste års hyppigt sendte fjernsynsreklamer er Nykredits reklame for boliglån. Nykredit stiller sig til rådighed, hvis man pludselig får behov for mindre plads (når barnet flytter hjemmefra), for mere plads (når graviditetstesten er positiv), får behov for én fælles bolig (når de unge flytter sammen) eller to boliger (når det aldrende går par fra hinanden). Også her eksponeres bolig behov $\mathrm{i}$ forhold til familiens cyklus og forandringer.

Nøgleord: Slægtskab, ufrivillig barnløshed, ting, hus/hjem.

\section{Litteratur}

Aries, Phillippe

1962 Centuries of Childhood. A Social History of Family Life. New York: Vintage Books.

Boholm, Åsa

1983 Swedish Kinship. An Exploration into Processes of Belonging and Continuity. Göteborg: Acta Universitatis Gothoburgensis.

Bonke, Jens

2002 Tid og velfærd. 2:26. København: Socialforskningsinstituttet.

Birdwell-Pheasant, Donna \& Denise Lawrence-Zúñiga

1999 Houses and Families in Europe. I: D. Birdwell-Pheasant \& D. Lawrence-Zúñiga (eds.): House Life: Space, Place, and Family in Europe. New York: Berg.

Carsten, Janet

1995 The Substance of Kinship and the Heat of the Hearth: Feeding, Personhood, and Relatedness among Malays in Pulau Langkawi. American Etnologist 22(2):22341.

Carsten, Janet \& Stephen Hugh-Jones (eds.)

1995 About the House. Lévi-Strauss and Beyond. Cambridge: Cambridge University Press.

Den Danske Ordbog

2004 København: Gyldendal.

Ejendomsavisen Danbolig

2008 Søndag 27. juli. Annoncetillæg i Morgenavisen Jyllandsposten og Politiken.

Empson, Rebecca

2007 Separating and Containing People and Things in Mongolia. I: A. Henare, M. Holbraad \& S. Wastell (eds.): Thinking Through Things. Theorising Artefacts Ethnographically. London: Routledge.

Gillespie, Susan D.

2000 Beyond Kinship. An Introduction. I: R.A. Joyce \& S.G. Gillespie (eds.): Beyond Kinship. Social and Material Reproduction in House Societies. Philadelphia: University of Pennsylvania Press.

Gillis, John

1996 A World of their Own Making. Myth, Ritual and the Quest for Family Values. New York: Basic Books. 
Gullestad, Marianne

$1984 \quad$ Kitchen Table Society. Oslo: Universitetsforlaget.

1993 Home Decoration as Popular Culture. I: T. del Valle (ed.): Gendered Anthropology. London: Routledge.

Hastrup, Kirsten

2004 Introduktion. Antropologiens vendinger. I: K. Hastrup (red.): Viden om verden. En grundbog i antropologisk analyse. København: Hans Reitzels Forlag.

2006 Designforskning. Mellem materialitet og socialitet. Copenhagen Working Papers on Design. København: Danmarks Designskole.

Henare, Amiria, Martin Holbraad \& Sari Wastell (eds.)

2007 Thinking Through Things. Theorising Artefacts Ethnographically. London: Routledge.

Joyce, Rosemary A. \& Susan G. Gillespie (eds.)

$2000 \quad$ Beyond Kinship. Social and Material Reproduction in House Societies Philadelphia: University of Pennsylvania Press.

Layne, Linda L.

$2000 \quad$ "He was a Real Baby with Baby Things": A Material Culture Analysis of Personhood, Parenthood and Pregnancy Loss. Journal of Material Culture 5(3): 321-45.

Low, Setha M.

1996 Spatializating Culture: The Social Production and Social Construction of Public Space in Costa Rica. American Ethnologist 23(4):861-79.

Löfgren, Orvar

2003 The Sweetness of Home. Class, Culture and Family Life in Sweden. I: S.M. Low \& D. Lawrence-Zúñiga (eds.): The Anthropology of Space and Place. Locating Culture. Oxford: Blackwell Publishing.

Ordbog over Det Danske Sprog

1966 Bind 8. København: Gyldendal.

Reddy, G. Prakash

1998 Danske dilemmaer. Mørke: Grevas Forlag.

Schneider, David M.

1980 American Kinship. A Cultural Account. Chicago: The University of Chicago Press.

Rosenbeck, Bente

1987 Kvindekøn. Den moderne kvindeligheds historie 1880-1980. København: Gyldendal.

Rosengren, Anette

1991 Två barn og eget Hus. Om kvinnors og mäns världar i småsamhället. Malmö: Carsson Bokförlag.

Ryborg, Alexandra Brandt

2008 Det sidste hjem - et studie af mandlige og kvindelige plejehjemsbeboeres socialitet. Bacheloressay. København: Institut for Antropologi.

Simpson, Bob

1997 Representations and Re-Presentation of Family. An Analysis of Divorce

Narratives. I: A. James, J. Hockey \& A. Dawson (eds.): After Writing Culture.

Epistemology and Praxis in Contemporary Anthropology. London: Routledge. 
Sjørslev, Inger

2007a Ritual, performance og socialitet. En introduktion. I: I. Sjørslev (red.): Scener for samvær. Ritualer, performance og socialitet. Århus: Århus Universitetsforlag.

2007b Ting og person: Bidrag til en socialitetsteknologi. I: I. Sjørslev (red.): Scener for samvær. Ritualer, performance og socialitet. Århus: Århus Universitetsforlag.

Tjørnhøj-Thomsen, Tine

1999a Tilblivelseshistorier. Barnløshed, slægtskab og forplantningsteknologi i Danmark. Ph.d.-række nr. 12. København: Institut for Antropologi.

1999b „Det føles ikke-mandigt på en måde“. Mænd og infertilitet. Kvinder, Køn \& Forskning 8(3):71-89.

2003 Samværet. Tilblivelser i tid og rum. I: K. Hastrup (red.): Ind i verden. En grundbog i antropologisk metode. København: Hans Reitzels Forlag.

2004 Slægtskab. Tilblivelse, forbundethed og fællesskab. I: K. Hastrup (red.): Viden om verden. En grundbog i antropologisk analyse. København: Hans Reitzels Forlag.

Winther, Ida Wentzel

2006 Hjemlighed. Kulturfænomenologiske studier. København: Danmarks Pædagogiske Universitets Forlag

Zelizer, Vivian A.

1985 Pricing the Priceless Child. The Changing Social Value of Children. New York: Basic Books. 